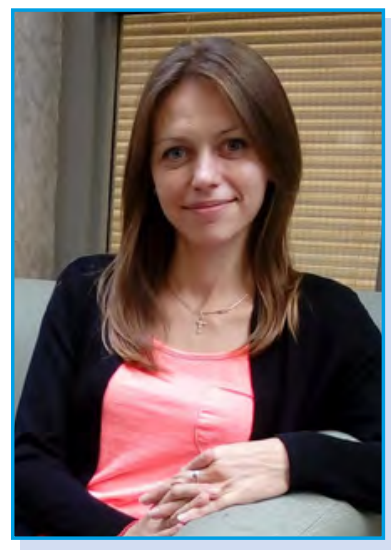

Наталія Захарчук - кандидат педагогічних наук, доцент (Україна), доктор філософії (Канада), дослідник, Університет Саскатчевану, м. Саскатун, Канада

Коло наукових інтересів: сучасні глобальні події та освітні тенденції (глобалізація, інтернаціоналізація, регіоналізація, діджеталізація та вплив пандемії COVID-19), університетська політика та управління освітою, міжнародна та порівняльна освіта, досвід міжнародних студентів, міжкультурне спілкування та професійний розвиток.

e-mail:naz212@usask.ca

https://orcid.org/0000-0002-9369-2872

УДК 37.005.33:378(045)

https://doi.org/10.32405/2411-1317-2021-4-37-47

\title{
ІНСТИТУЦІЙНІ ІНІЦІАТИВИ ТА ПРАКТИКИ ПІДВИЩЕННЯ УСПІШНОСТІ СТУДЕНТІВ: ІЗ ДОСВІДУ ЗАХІДНИХ УНIВЕРСИТЕТІВ
}

У статті аналізується доробок західних вчених щодо успішності студентів у закладах вищої освіти. Автор визначає успішність студентів як інтегрований продукт, сукупну відповідальність освітньої установи за успішну адаптацію студентів до навчального процесу та відповідальність самих студентів. У цьому сенсі інституційна відповідальність є передумовою успішності студентів. Стаття пропонує класифікувати інституційні ініціативи підвищення успішності студентів на інформаційно-пошукові, ініціативи надання підтримки та підвищення якості послуг. Наводяться приклади кращих практик західних університетів у межах запропонованих категорій. На основі їх аналізу автор виділяє основні принципи, на яких грунтуються ефективні інституційні ініціативи підвищення успішності студентів.

Ключові слова: інституційна ініціатива; успішність студентів; вищий навчальний заклад; інституційна відповідальність; особиста відповідальність студента.

Постановка проблеми. Майже усі підсвідомо ототожнюють поняття вищої освіти та успіху. Студенти приходять до навчального закладу з наміром стати успішними. Так само батьки та інші стейкхолдери мають певні очікування щодо успіху студентів у навчальних закладах. Незважаючи на непохитну віру у цей успіх, показники успішності студентів українських та західних університетів засвідчують, що студентам все ж потрібно подолати довгий шлях перед тим, як успішно закінчити вищий освітній заклад. Цей шлях починається з моменту вступу до вищого освітнього закладу та адаптації до студентського життя.

Адаптація до нового навчального та соціального середовища - не лише відповідальність самого студента. Успіх студентів не базується на підході «головне не заважати» («get out of their way») (Light, 2001, c. 3), а не на формуванні середовища, що полегшує навчання. Успішність студентів у виші - це інтегрований продукт. Він включає цінності та принципи освітнього закладу, програми та політику щодо підтримання високого рівня діяльності освітніх інституцій, найкращі викладацькі практики, зусилля як освітнього закладу, так і викладачів щодо залучення студентів до університетського життя. 
Аналіз останніх досліджень і публікацій. Успішність студентів є однією з головних проблем у західній як педагогічній, так і управлінській практиці. Це відображається у зростанні наукових праць та досліджень у відповідних освітніх галузях. Досвіду студентів у перший рік їхнього навчання в коледжах та університетах приділяли велику увагу у своїх роботах К. Вілсон (Wilson, 2009), Дж. Ейнфальт і Дж. Терлі (Einfalt and Turley, 2013), К. Кінг (King, 2021), Дж. Кузео (Cuseo, 2020), К. Пурнелл, Р. Маккарті та М. Маклеод (Purnell, McCarthy, McLeod, 2010), В. Тінто (Tinto, 2005), М. Тукібаєва та Р.М. Гоньє (Tukibayeva, Gonyea, 2014). Менше досліджень присвячено життю студентів на другому та старших курсах університету. Успіх студентів у системі вищої освіти розглядається через призму індивідуального часу та зусиль, які докладають самі студенти у процесі навчання К. Вілсоном (Wilson, 2009), Дж. Кузео (Cuseo, 2020), Г.Д. Кухом (Kuh, 2005), С.А. Нонісом і Г.I. Хадсоном (Nonis, Hudson, 2006). Для позитивного досвіду студентів у вищих закладах освіти мають важливе значення почуття та цілі студентів (Wilson, 2009), (Kennett, Keefer, 2006), (Rosenbaum, Ben-Ari, 1985), а також такі їх індивідуальні особливості та особисті риси, такі як наполегливість, самосвідомість, самоефективність тощо (Cuseo, 2012), (Shaffer, Eshbach and Santiago-Blay, 2015). Проте не менш важливими, на думку С.С. Гронке i C. А. Вузлі (Graunke, Woosley, 2005), Д. Дж. Кеннета і М. Дж. Ріда (Kennett, Reed, 2009), К. Кінга (King, 2021) та В. Тінто (Tinto, 2012), є зовнішні фактори, які впливають на адаптацію студентів та сприяють їхній успішності у вишах.

Західні вчені пропонують різні моделі адаптації студентів до вищих навчальних закладів. Наприклад, теорія переходу В. Тінто (Tinto’s transition theory) пояснює перехід студентів від загальноосвітньої школи до університету через механізм подолання бар'єрів, особисту наполегливість та настирність у новому середовищі (Tinto, 1987). Теорія набутої винахідливості M. Розенбаума (Rosenbaum's theory of learned resourcefulness) описує академічну та неакадемічну успішність студентів як результат засвоєних навичок винахідливості з боку самого студента (Rosenbaum, Ben-Ari, 1985).

А.В. Остін (Astin, 1999) та K. Вілсон (Wilson, 2009) сфокусувалися на додатковому компоненті успішності студентів - інституційній відповідальності за успіх та розвиток студентів у закладах вищої освіті. Теорія розвитку та залучення студентів (the developmental theory of student involvement), запропонована А.В. Остіном, полягає в урахуванні дуалістичної відповідальності щодо студентської успішності: з боку самого студента та з боку закладу вищої освіти. За словами А.В. Остіна, ця теорія базується як на дослідженнях розвитку студентів, так і на забезпеченні ефективного навчального середовища. Заснована на принципах психоаналізу та класичної теорії навчання, теорія розвитку та залучення студентів визнає вирішальним вплив середовища на розвиток студентів. У своїй теорії А.В. Остін підкреслює прямий зв'язок між ефективністю будь-якої освітньої політики чи практики та її здатністю підвищувати успішність студентів шляхом залучення до різних аспектів студентського життя (Astin, 1999). Отже, якісні та кількісні показники успішності студентів пов'язані не лише з навчанням та розвитком студентів в освітній програмі, але й із їхнім залученням до університетського життя. Так само, на думку К. Вілсона, основою ефективного та успішного досвіду студентів є усвідомлення, що цей досвід залежить як від студентської наполегливості та почуття відповідальності, так і від зобов'язань та відповідальності самого вищого навчального закладу щодо підтримки студентів у процесі адаптації до освітнього закладу та у процесі подальшого навчання (Wilson, 2009).

Метою статті є: 1) розглянути доробки західних учених щодо успішності студентів у закладах вищої освіти; 2) обговорити роль інституційної відповідальності, тобто відповідальності освітньої установи, за успішну адаптацію студентів до навчального процесу; 3) запропонувати класифікацію інституційних ініціатив щодо підвищення успішності студентів та проаналізувати кращі практики західних університетів в межах запропонованих категорій; 4) виділити основні принципи, на яких грунтуються ефективні інституційні ініціативи підвищення успішності студентів.

Виклад основного матеріалу. Інституційна відповідальність за успішну адаптацію студентів стала предметом масштабних досліджень у США (Light, 2001), (Gahagan and Hunter, 2006), 
(Coker and Porter, 2015), (Kuh, Kinzie, Schuh and Whitt, 2011), (Strom P., and Strom R., 2013). У літературі можна знайти не так багато прикладів інституційних інііатив, що сприяють успіху студентів в інших країнах. До прикладу, К. Пурнелл, Р. Маккарті та М. Маклеод аналізують досвід австралійського університету щодо раннього профілювання та підтримку студентів, які перебувають у групі ризику (Purnell, McCarthy, McLeod, 2010). Подібним чином C.К. Шаффер, Б.Е. Ешбах та Дж.А. Сантьяго-Блей розглядають моделі парних курсів у британських університетах, які підтримують та допомагають недостатньо підготовленим студентів першого курcy (Shaffer, Eshbach and Santiago-Blay, 2015). T. А. Сейферт, К. Арнольд, Дж. Берроу та А. Браун обговорюють інституційні ініціативи у канадському освітньому середовищі на прикладі вищих навчальних закладів Онтаріо (Seifert, Arnold, Burrow J., Brown A., 2011). Д. Харді Кокс і К.К. Стрендж досліджують діяльність студентських служб та сервісів у канадських університетах (Hardy Cox, Strange, 2010). Результати цих західних інституційних практик засвідчують, що студенти частіше досягають успіху у своєму академічному та соціальному житті, якщо вищі навчальні заклади прагнуть підвищити успішність студентів. Аналіз західної літератури щодо досвіду студентів у вищих навчальних закладах дозволяє зробити висновок, що успішність студента $є$ як відповідальністю особистості, так відповідальністю і освітньої установи (див. Рис. 1). Більше того, саме визначення успішності студента як сприятливого або бажаного результату, що включає розвиток особистості студента та успішне закінчення освітнього закладу (Kuh, 2005), містить у собі натяк на подвійну відповідальність особистості та інституції.

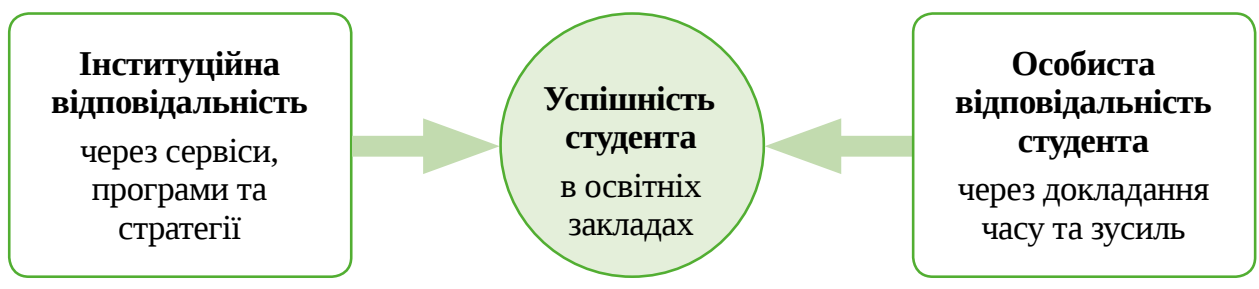

Рис. 1. Інституційна та особиста відповідальність за успішність студента

Успішність студентів - це питання так званого «залучення» студентів, яке Г.Д. Кух пояснює «як час і зусилля, які студенти приділяють навчанню та пов'язаній з ними діяльності, а також те, як заклади організовують навчання та які послуги надають, щоб спонукати студентів брати участь в університетському житті і отримувати користь від такої діяльності» (Kuh, 2005, с. 1). Тут не йдеться про зменшення ролі особистої відповідальності студентів за свою успішність, а лише акцентується увага на студентській успішності в інституційному контексті, досліджуючи інституційні послуги, програми та стратегії для оптимізації академічного та соціального досвіду студентів. Іншими словами, інституційну відповідальність у цьому сенсі можна вважати передумовою студентського успіху.

За В. Тінто, інституційна відповідальність - не просто місія освітньої установи. Установи, що прагнуть підвищити успішність студентів, повинні бути готовими інвестувати ресурси та забезпечувати системи стимулів та винагород необхідних для цієї мети (Tinto, 2005). Вони повинні шукати різноманітні способи ії досягнення, наприклад, інвестувати в життя, кар’єру та розвиток своїх студентів (Bain, 2004). Бажання інвестувати такі інституційні ресурси як час, кошти та зусилля у якість навчання та досвід студентів проявляється по-різному. Ці прояви можуть включати освітню філософію, часте нагадування викладачам та працівникам про прагнення та відданість їхнього навчального закладу, якісні програми та практичні дії, культивування етики постійного вдосконалення, створення простору для забезпечення високої ефективності учасників навчального процесу (Kuh, 2005).

Тобто, інституційна відповідальність за успішність студентів - це готовність з боку освітніх установ інвестувати зусилля та ресурси у якість академічного та соціального досвіду студентів. 
Ця відповідальність зазвичай окреслюється в установчому статутному документі (наприклад, інституційній місії, баченні, тощо), політиці та стратегії, якісних програмах та практиках, відданому керівництві та викладачах, постійному вдосконаленні етики освітньої установи, створенні сприятливого навчального середовища, тощо.

Аналізуючи досвід студентів, К. Вілсон визнає, що ефективне пристосування до освітнього закладу та успішність студента - це безперервний процес, якому сприяють ефективні та дієві інституційні практики (Wilson, 2009). Більше того, вчений розглядає так званий студентський цикл (the student lifecycle) як корисну концепцію для забезпечення відповідної своєчасної допомоги студенту на різних етапах його навчання в освітніх закладах, починаючи зі вступу, складання іспитів, проходження практики, тощо (Wilson, 2009). Так, головною метою усіх західних інституційних ініціатив є сприяння успішності студентів шляхом зосередження уваги на студентському досвіді, розробці різних форм підтримки студентів, упровадженні ефективних програм та практик. Наприклад, університетські містечка пропонують різноманітні спеціалізовані ресурси, щоб допомогти студентам краще орієнтуватися на кампусах. Різні навчальні центри, центри академічного консультування та підтримки, бібліотеки, консультаційні служби та служби допомоги у кар'єрному розвитку спрямовані на підтримку різноманітних академічних та неакадемічних аспектів студентського життя. Більше того, західні університети пропонують ініціативи й для покращення існуючих практик та послуг. Аналіз літератури щодо інституційних ініціатив та практик, спрямованих на успіх студентів вищих навчальних закладів, дозволяє згрупувати ці послуги, програми та стратегії у три великі категорії відповідно до їх основних цілей. Отже, у цій статті інституційні ініціативи класифікуються як інформаційно-пошукові (exploratory initiatives), ініціативи надання підтримки (supporting initiatives) та підвищення якості послуг (quality enhancing initiatives).

Інформаційно-пошукові ініціативи спрямовані на дослідження широкого кола питань, пов'язаних 3 різними аспектами академічного та соціального життя студентів в університеті, визначення та вивчення пріоритетів і основних потреб студентів за допомогою кількісних та якісних досліджень. Основною метою цього типу інституційних ініціатив є визначення потреб, проблем та пріоритетів студентів для розуміння подальших інституційних кроків та стратегічних напрямів розвитку. Окрім інформації про основні проблеми, з якими стикаються студенти, та студентські потреби, такі ініціативи можуть надавати інформацію про динаміку вже упроваджених програм та практик. Прикладами інформаційно-пошукових ініціатив можуть бути Гарвардський аналітичний проект (Harvard Assessment Project), Загальні показники закінчення навчання у коледжах (Common College Completion Metrics) та Опитувальник готовності студентів (Student Readiness Questionnaire).

Так, у 2001 році Р. Дж. Лайт описав масштабний аналітичний проєкт, який відбувся у Гарварді та до якого було залучено близько 1600 студентів (Light, 2001). Цей проєкт є наочним прикладом інформаційно-пошукової інституційної ініціативи, оскільки його метою було з'ясувати, яким чином студенти можуть отримати максимальну користь від навчання в університеті. Водночас проєкт був спрямований і на те, як втілити отриману інформацію у університетську практику, тобто, визначити ефективні шляхи, якими викладачі та керівники університетів можуть допомогти студентам отримати максимум від їхнього навчання.

П.С. Стром та Р.Д. Стром описали ще одну інституційну ініціативу, яку можна віднести до категорії інформаційно-пошукових (Strom P., and Strom R., 2013). Через низькі показники успішності у вищій освіті, необхідність збільшення кількості випускників коледжів, а також спричинені цим несприятливі економічні та соціальні наслідки, у США було створено систему Загальних показників щодо успішного закінчення коледжів. За її допомогою були встановлені основні причини, чому студенти залишають освітні заклади. Основними з таких причин стали неможливість поєднувати навчання з роботою, недостатня підготовленість до навчання в університетах, фінансові проблеми, невдало обрана кар’єра та невелике значення вищої освіти в очах студентів. Цей інформаційно-пошуковий проєкт дав можливість запровадити нові інституційні реформи, а також приділити більше уваги співробітництву між студентами, викладачами, бать- 
ками та громадою. Окрім того була переглянута політика щодо студентських позик та діяльності професійно-технічних освітніх закладів (Strom P., and Strom R., 2013).

Центральний університет Квінсленда в Австралії застосував практику раннього профілювання, яку також можна вважати прикладом інформаційно-пошукової ініціативи. К. Пурнелл, Р. Маккарті та М. Маклеод досліджували процеси раннього профілювання та подальшої підтримки студентів, що перебувають у зоні ризику (Purnell, McCarthy, McLeod, 2010). Ця ініціатива була розроблена на основі внутрішніх досліджень щодо поліпшення успішності студентів першого курсу. Опитувальник готовності студентів дозволив визначити рівень готовності студентів, їх очікування від освітньої програми та ключових фактори академічної успішності. Отримані дані дозволили розділити студентів першого курсу на три категорії з високою, середньою та низькою готовністю до коледжу. Також опитувальник дав можливість визначити індивідуальні навчальні потреби студентів та найкращі способи, якими університет зміг би задовольнити ці потреби. За результатами опитування були розроблені нові предмети, удосконалені існуючі практики та впроваджені служби підтримки студентів у період адаптації до університетського життя (Purnell, McCarthy, McLeod, 2010).

Упровадження інформаційно-пошукових ініціатив, таких, як визначення показників успішності чи опитувальники готовності, сприяють не лише реалізації конкретних стратегій освітніми закладами, але й у перспективі ведуть до покращення якості вищої освіти та дають підстави для потенційних освітніх реформ.

Ініціативи надання підтримки є наступним логічним кроком після інформаційно-пошукових. Основною метою таких ініціатив є надання своєчасної підтримки студентам на основі уже здобутої інформації щодо їх потреб та труднощів. Ця категорія ініціатив спрямована на надання допомоги в різних сферах студентського життя (наприклад, соціальній, академічній, професійній, тощо). Увага зазвичай концентрується або на а) забезпеченні результатів навчання певного періоду життя студента, або б) на застосуванні комплексних підходів, що стосуються загального освітнього процесу - від першого курсу програми до завершення процесу навчання. Якщо навчальний заклад пріоритезує успішність студентів, він не відокремлює інформаційно-пошукові ініціативи від ініціатив надання підтримки, оскільки за першими негайно слідують і наступні. Отже, інформаційно-пошукові ініціативи можна вважати передумовою для реалізації або вдосконалення певної ініціативи з надання підтримки студентам чи підвищення якості послуг.

Значна частина інституційних ініціатив щодо надання підтримки студентам зосереджена насамперед на успішності студентів на першому або останньому курсах навчання. Більшість інституційних програм вирішують проблеми та потреби студентів на початку або на завершальному етапах їх академічної подорожі. Прикладом таких інституційних ініціатив може бути модель спільної підтримки для підвищення успішності студентів першого курсу, заснована на співпраці та партнерстві усіх університетських підрозділів. Дж. Ейнфальт та Дж. Терлі досліджують таку моделі спільної підтримки студентів, що функціонує в Університеті Сонячного Узбережжя в Австралії з 2008 року (Einfalt and Turley, 2013). Основною ідеєю такої інституційної ініціативи є не залучення лише окремого конкретного підрозділу чи відділу університету до вирішення певних студентських питань, а співпраця усієї установи, кооперативні дії усіх відділів щодо найоптимальнішого надання підтримки студентам. Ефективність такої практики досягається завдяки співпраці між координаторами курсів, радниками академічних програм та бібліотекарами, як основними помічниками у дослідницькій діяльності. Така тристороння співпраця спрямована на підтримку студентів першого курсу та на забезпечення легшого доступу до широкого спектру служб та університетських центрів. Як наслідок, покращується обізнаність студентів про навчальний процес та подальші перспективи, ставлення до власних досягнень, підвищується успішність студентів у виконанні індивідуальних завдань (Einfalt and Turley, 2013).

На противагу численним ініціативам щодо надання підтримки студентам першого курсу, другий курс визнається дещо «занедбаним» роком у студентському житті. Наприклад, Б. Ф. Тоболовський, порівнявши труднощі студентів першого курсу та другокурсників, робить висновки, 
що кількість проблем, з якими зіштовхуються студенти другого курсу в західних університетах більша, а перехід на другий курс, насправді, складніший (Tobolowsky, 2008). Цей перехідний період пов’язаний $з$ прийняттям рішень, які впливають на наступні роки навчання: вибір спеціалізації, вибір потенційної кар’єри, вибір навчальних курсів, які б відповідали окресленій меті. Так, занепокоєння щодо успішності студентів на другому курсі призвело до цілого ряду інституційних ініціатив. Наприклад, у США деякі приватні навчальні заклади розробити чотирирічні плани, які чітко зазначають конкретні навчальні результати для кожного із чотирьох років навчання та конкретні дії закладів щодо досягнення цих результатів (Tobolowsky, 2008).

3 іншого боку, ілюстративним прикладом комплексного підходу є ініціативи з досвідного навчання в Університеті Ілона. Дж. С. Кокер та Д. Дж. Портер описують переваги досвідного навчання для максимізації успіху студентів в університеті (Coker and Porter, 2015). Численні студентські обговорення та співпраця викладацького складу допомогли визначити, що застосування кількох видів досвідного навчання (наприклад, навчання за кордоном, стажування, дослідження, практики керівництва тощо) приводить до кращих академічних результатів та здобуття кар'єрних переваг. Більше того, немає різниці, до яких саме видів досвідного навчання залучаються студенти. За словами Дж.С. Кокера та Д. Дж. Портера, ключовим є використання саме кількох практик досвідного навчання, на противагу лише одній. Освітній установі потрібно забезпечити широкий вибір можливостей для досвідного навчання, які б відповідали інтересам та потребам студентів, поширювати інформацію про можливості досвідного навчання та надавати усім студентам доступ до цих програм шляхом створення структур фінансової допомоги (Coker and Porter, 2015).

Поширеними у західних університетах є так звані високоефективні практики (high-impact practices), тобто, діяльність, яка приносить користь студентам та заохочує до навчання (Kuh, 2013). Вони розглядаються як вид ініціатив, спрямованих на підтримку студентів. Такі практики зазвичай вимагають від студента значної кількості часу та зусиль, надають можливості для співпраці з викладачами та колегами, спонукають студентів виходити із зони комфорту, створюють умови для сприйняття конструктивної критики, надають можливості студентам застосувати знання поза аудиторією та сприяють глибокому навчанню (deep learning) (Tukibayeva, Gonyea, 2014).

Для ілюстрації розглянемо практики навчальних спільнот (learning communities). У 2013 році Г.Д. Кух проаналізував стратегічні зусилля трьох освітніх установ щодо забезпечення позитивного досвіду студентів, підвищення їх успішності та покращення інституційної ефективності: навчальні спільноти в Валенсійському коледжі, загальну інтелектуальну ініціативу Пайдея в коледжі Лютера та практикум в університеті Ілона (Kuh, 2013). Результатом усіх зазначених інституційних ініціатив стали підвищені показниками успішності студентів. Загалом, Г. Д. Кух наголошує, що ці приклади не слід розглядати як дорожні карти до інституційних змін, а лише як ініціативи, що носять певні повчальні елементи, які слід враховувати. Наприклад, ці установи систематично використовують високоефективні практики, таким чином зміцнюючи зв’язок студентів із обраними ними установами та узгоджуючи інституційні цінності та цілі із потребами студентів (Kuh, 2013).

Загалом, переосмислення західного досвіду інституційних ініціатив підтримки студентів це крок до створення цілісного освітнього середовища та розвитку стійких практик підвищення успішності студентів. Це дієві способи максимізації успіху студентів шляхом посилення їх мотивації до навчання та набуття різностороннього досвіду, що відповідає потребам та інтересам студентів.

Ініціативи підвищення якості послуг можна охарактеризувати як такі, які засновані на переконанні, що в університеті має місце лише ефективне викладання. Метою ініціатив щодо підвищення якості є надання адміністраторам, викладачам та радникам можливостей для подальшого професійного розвитку, підвищення якості їх роботи, підтримки якості програм і навчальних планів та розробки курсів. Прикладами таких ініціатив можуть бути проекти щодо вдосконалення викладання, курси з розвитку персоналу, аналізи результатів діяльності, аналіз та самоаналіз практик викладання, студентська оцінка курсів, розробка інтегрованих навчальних програм, тощо. 
Навчання залежить від викладання, а не є ізольованим досвідом. В. Тінто підкреслює, що будь-яка інституційна політика, спрямована на підвищення успішності студентів, повинна вирішувати питання ефективності навчальних програм, ефективності викладання та педагогічної діяльності (Tinto, 2005). За словами В. Тінто, університети потребують спеціальних програм для нових викладачів, систем підвищення кваліфікації кадрів, систем заохочення та винагороди для викладачів, програм партнерської співпраці з іншими освітніми установами (Tinto, 2005).

Прикладом ініціатив підвищення якості є практики двадцяти установ у США, які були залучені у проект документування ефективних навчальних практик (Documenting Effective Education Practice). Г.Д. Кух, Дж. Кінзі, Дж.Г. Шух та Е. Дж. Уітт проаналізували досвід цих навчальних закладів у важкі для них часи (Kuh, Kinzie, Schuh and Whitt, 2011). У межах проєкту Г.Д. Кух та інші зосередилися на двадцяти установах з різними місіями та структурними особливостями, які зуміли підтримати успішність своїх студентів, коли самим закладам доводилося працювати у складних обставинах. Автори проілюстрували дії цих закладів та навели приклади труднощів, які вони подолали для збереження якості освітніх послуг. Їх аналіз дозволив виділити основні чотири умови для підтримання ефективної освітньої діяльності за важких часів: а) глибоке і постійне критичне переосмислення власної політики; б) рішення щодо політики, програми та практик приймаються на основі якісних та кількісних даних про успішність студентів; в) постійна співпраця академічних підрозділів зі студентами; та г) зацікавленість викладачів та співробітників у студентській успішності (Kuh, Kinzie, Schuh and Whitt, 2011).

Аналіз досвіду західних освітніх установ щодо впровадження різних програм та практик, спрямованих на підвищення успішності студентів, дає можливість визначити основні характеристик ефективних ініціатив. Згідно Дж. Кузео, не тільки що, але й як впливає на ефективність інституційних ініціатив (Cuseo, 2012). Таким чином, ефективні інституційні ініціативи базуються не лише на змісті самих програм та практик, а й враховують процес їх реалізації. Так, Дж. Кузео виділив загальні принципи ефективності будь-яких інституційних програм та практик: зорієнтованість на студентів, проактивність (спрямованість на попередження проблем, ніж на їх вирішення), всеохопливість (забезпечує підтримку переважної більшості студентів), різноманітність (ініціативи розроблені з урахуванням різних студентських потреб), синергійність (побудова партнерських відносин між різними підрозділами), централізованість та емпіричність (ініціативи підкріплюються даними досліджень) (Cuseo, 2012).

На думку В. Тінто, освітні заклади повинні: створити різноманітні можливості для того, щоб нові студенти набували умінь та навичок, необхідних для успішного навчання; будувати відносини зі студентами поза формальними сферами академічного життя; створювати системи підтримки студентів та надавати цю підтримку якомога раніше; і нести відповідальність перед своїми студентами (Tinto, 1987).

Широкомасштабне дослідження інституційних ініціатив у США, проведене Національним ресурсним центром для студентів першого курсу та студентів у перехідний період, показало, що ключову роль у спішності учнів відіграє саме діяльність освітніх установ. Освітні заклади з найбільшими показниками успішності студентів докладають максимум зусиль, щоб викликати у своїх студентів почуття приналежності до університетської спільноти, сприяють соціальному залученню студентів та взаємодії викладачів та студентів, заохочують до вивчення основних шляхів кар'єрного розвитку та сприянню залученню студентів до управляння як навчальним процесом, так і освітнім закладом (Tobolowsky, 2008). Такі ініціативи є дієвими не лише для підтримання успішності студентів першого курсу та студентів у перехідний період. Вони є доречними для студентів будь-яких спеціальностей та на будь-якому році їхнього навчання.

Висновки та перспективи подальших досліджень. Західна література надає великого значення дискурсу про успішність студентів протягом першого року навчання та забезпечення навчальних можливостей для посилення мотивації студентів. Розглядаються найкращі стратегій, що сприяють успіху студентів протягом усіх років навчання у освітніх установах. У літературі успіх студентів аналізується через призму студентських обов'язків та зусиль, факторів, що 
впливають на успішне закінчення навчальних закладів, моделей залучення студентів до університетського життя. Успіх студентів розглядається як інтегрований продукт індивідуальної відповідальності студентів через інвестиції часу та зусиль та інституційної відповідальності через забезпечення відповідних послуги, програми та стратегії. Більше того, основний акцент ставиться саме на відповідальності освітніх установ за студентську успішність.

Аналіз західних інституційних ініціатив, спрямованих на успішність студентів, дозволив згрупувати таки послуги, програми та стратегії у три великі категорії відповідно до основних цілей: інформаційно-пошукові ініціативи, ініціативи надання підтримки та підвищення якості послуг. Проаналізувавши ефективні практики західних освітніх установ, ми можемо виділили загальні принципи, якими вони керуються при розробці та впровадженні освітніх послуг та програм. Цими принципами є:

- надання рівних можливостей та підтримки для всіх студентів, незалежно від курсу навчання;

- залучення студентів не лише до академічної діяльності в університеті, але й створення неакадемічних (соціальних, волонтерських, екологічних, тощо) програм за межами університетів;

- якісний та кількісний моніторинг ефективності будь-якої інституційної ініціативи;

- реалізація програм та стратегій, спрямованих на залучення студентів до університетського життя з перших днів їх студентства або навіть раніше;

- створення почуття спільноти через соціальну залученість, взаємодію викладачів і студентів, тісного спілкування студентів різних спеціальностей та років навчання;

- постійне оцінювання та вдосконалення існуючих програм та практик відповідно до вимог часу.

У той же час, слід пам'ятати, що дотримання усіх зазначених принципів не може зробити інституційні зусилля повністю успішними та ефективними, якщо студент не бажає використовувати інституційні ресурси. Результативність освітніх закладів полягає не в тому, щоб робити все можливе для студента. Діяльність освітніх закладів буде успішною, лише коли сам студент буде вмотивований користуватися програмами, засобами, можливостями, які пропонуються освітніми установами.

\section{Використані джерела}

[1] Light, R. J. (2001). Making the Most of College: Students Speak Their Minds. Cambridge, MA, USA.

[2] Wilson, K. (2009, Jun.29-Jul.1). Success in first year: The impact of institutional, programmatic and personal interventions on an effective and sustainable first-year student experience, presented at the 12th Pacific Rim First Year in Higher Educ. Conf., Brisbane. www.fyhe.com.au/past_papers/papers09/ppts/Keithia_Wilson_paper.pdf

[3] Einfalt, J. and Turley, J. (2013). Partnerships for success: A collaborative support model to enhance the firstyear student experience. The Int. J. of the First Year in Higher Educ., vol. 4, no. 1, pp. 73-84, 2013. DOI: https://doi.org/10.5204/intjfyhe.v4i1.153.

[4] King, C. (2021, June 7). Factors related to the persistence of first year college students at four-year colleges and universities: A paradigm shift. https://docplayer.net/21222033-Factors-related-to-the-persistence-of-firstyear-college-students-at-four-year-colleges-and-universities-a-paradigm-shift.html.

[5] Cuseo, J. (2020). What all first-year students should know: The most potent, research-based principles of college success. https://www.researchgate.net/profile/Joe-Cuseo/publication/265011122_What_All_ First-Year_Students_Should_Know_The_Most_Potent_Research-Based_Principles_of_College_Success/ links/547ca2fc0cf27ed978622ab9/What-All-First-Year-Students-Should-Know-The-Most-Potent-ResearchBased-Principles-of-College-Success.pdf.

[6] Purnell, K., McCarthy, R., M. McLeod. (2010). Student success at university: Using early profiling and interventions to support learning. Studies in Learn., Evaluation Innov. \& Develop., vol. 7, no. 3, pp. 77-86. http://sleid.cqu.edu.au

[7] Tinto, V. (2005, Jan. 15). Taking student success seriously: Rethinking the first year of college, The 9th Annual Intersession Academic Affairs Forum, Fullerton, CA, USA. http://www.uky.edu/ie/sites/www.uky.edu.ie/files/ uploads/CF 
[8] Tukibayeva, M., Gonyea, R. (2014). High-impact practices and the first-year student. New Directions for Institutional Res., vol. 160, pp. 19-35, 2014. DOI: https://doi.org/10.1002/ir.20059.

[9] Gahagan, J. and Hunter, M. (2006). The second-year experience: Turning attention to the academy’s middle children. About Campus: Enriching the Student Learn. Experience, vol. 11, no. 3, pp. 17-22. Available: 10.1002/abc.168.

[10] Graunke, S. S. and Woosley, S. A. (2005) An exploration of the factors that affect the academic success of college sophomores. The College Student J., vol. 39, no. 2, pp. 367-377. Available: http://www.freepatentsonline. com/article/College-Student-Journal/133606107.html

[11] Tobolowsky, B. (2008). Sophomores in transition: The forgotten year. New Directions for Higher Educ., vol. 2008, no. 144, pp. 59-67. Available: 10.1002/he.326.

[12] Kuh, G. D. (2005). Promoting Student Success: What Campus Leaders Can Do (Occasional Paper no. 1. Bloomington, IN, USA: Indiana Univ. Center for Postsecondary Res. Available: http://nsse.indiana.edu/ Institutional_Report/DEEP_brief_1.pdf

[13] Nonis, S. and Hudson, G. (2006). Academic performance of college students: Influence of time spent studying and working. J. of Educ. for Bus., vol. 81, no. 3, pp. 151-159. Available: 10.3200/joeb.81.3.151-159.

[14] Kennett, D. J. and Keefer, K. (2006). Impact of learned resourcefulness and theories of intelligence on academic achievement of university students: An integrated approach. Educational Psychol., vol. 26, no. 3, pp. 441-457. Available: 10.1080/01443410500342062

[15] Rosenbaum, M. and Ben-Ari, K. (1985). Learned helplessness and learned resourcefulness: Effects of noncontingent success and failure on individuals differing in self-control skills. J. of Personality \& Social Psychol., vol. 48, no. 1, pp. 198-215.

[16] Cuseo, J. (2012). Student success: Definition, outcomes, principles and practices. Esource for College Transitions (Electron. Newslett.), Available: http://www.fye.uconn.edu/12F_Wk_Digest/September/Weekly_2012_09_24/ PDF's/Cuseo_Student_Success.pdf

[17] Shaffer, S. C., Eshbach, B. E., and Santiago-Blay, J. A. (2015). A dual approach to fostering under-prepared student success: Focusing on doing and becoming. InSight: A J. of Scholarly Teaching, vol. 10, pp. 79-91. Available: https://files.eric.ed.gov/fulltext/EJ1074057.pdf

[18] Kennett, D. J. and Reed, M. J. (2009). Factors influencing academic success and retention following a 1styear post-secondary success course. Educational Res. and Eval., vol. 15, no. 2, pp. 153-166. Available: 10.1080/13803610902804382

[19] Tinto, V. (2012). Enhancing student success: Taking the classroom success seriously. The Int. J. of the First Year in Higher Educ., vol. 3, no. 1, pp. 1-8. Available: 10.5204/intjfyhe.v2i1.119

[20] Tinto, V. (1987). Leaving College: Rethinking the Causes and Cures of Student Attrition. Chicago, IL, USA: Univ. of Chicago Press.

[21] Astin, A.W. (1999). Student involvement: A developmental theory for higher education. J. of College Student Develop., vol. 40, no. 5, pp. 518-529. Available: https://www.middlesex.mass.edu/ace/downloads/ astininv.pdf

[22] Coker, J. S. and Porter, D. J. (2015). Maximizing experiential learning for student success. Change: The Mag. of Higher Learn., vol. 47, no. 1, pp. 66-72. Available: 10.1080/00091383.2015.996101

[23] Kuh, G. D., Kinzie, J., Schuh, J. H, and Whitt, E. J. (2011). Fostering student success in hard times,” Change: The Mag. of Higher Learn., vol. 43, no. 4, pp. 13-19. Available: 10.1080/00091383.2011.585311

[24] Strom, P. S. and Strom, R. D. (2013). Collaboration and support for student success. Community College J. of Res. and Pract., vol. 37, no. 8, pp. 585-595. Available: 10.1080/10668926.2012.753851

[25] Seifert, T.A., Arnold, C., Burrow, J., and Brown, A. (2011). Supporting Student Success: The Role of Student Services within Ontario's Postsecondary Institutions. Toronto, ON, Canada: Higher Educ. Qual. Council of Ontario.

[26] Hardy Cox, D. and Strange, C. C. (2010). Achieving Student Success: Effective Student Services in Canadian Higher Education. Montreal \& Kingston, QB, Canada: McGill-Queens Univ. Press.

[27] Bain, K. (2004). What the Best College Teachers Do. Cambridge, MA, USA: Harvard Univ. Press.

[28] Kuh, G. D. (2013). Promise in action: Examples of institutional success. New Directions for Higher Educ., vol. 161, pp. 81-89. Available: 10.1002/he.20048 


\section{References}

[1] Light, R. J. (2001). Making the Most of College: Students Speak Their Minds. Cambridge, MA, USA. (in English).

[2] Wilson, K. (2009, Jun.29-Jul.1). Success in first year: The impact of institutional, programmatic and personal interventions on an effective and sustainable first-year student experience, presented at the 12th Pacific Rim First Year in Higher Educ. Conf., Brisbane. www.fyhe.com.au/past_papers/papers09/ppts/Keithia_Wilson_paper. pdf (in English).

[3] Einfalt, J. and Turley, J. (2013). Partnerships for success: A collaborative support model to enhance the firstyear student experience. The Int. J. of the First Year in Higher Educ., vol. 4, no. 1, pp. 73-84, 2013. DOI: https://doi.org/10.5204/intjfyhe.v4i1.153. (in English).

[4] King, C. (2021, June 7). Factors related to the persistence of first year college students at four-year colleges and universities: A paradigm shift. https:/docplayer.net/21222033-Factors-related-to-the-persistence-of-firstyear-college-students-at-four-year-colleges-and-universities-a-paradigm-shift.html. (in English).

[5] Cuseo, J. (2020). What all first-year students should know: The most potent, research-based principles of college success. https://www.researchgate.net/profile/Joe-Cuseo/publication/265011122_What_All_ First-Year_Students_Should_Know_The_Most_Potent_Research-Based_Principles_of_College_Success/ links/547ca2fc0cf27ed978622ab9/What-All-First-Year-Students-Should-Know-The-Most-Potent-ResearchBased-Principles-of-College-Success.pdf. (in English).

[6] Purnell, K., McCarthy, R., M. McLeod. (2010). Student success at university: Using early profiling and interventions to support learning. Studies in Learn., Evaluation Innov. \& Develop., vol. 7, no. 3, pp. $77-86$. http://sleid.cqu.edu.au (in English).

[7] Tinto, V. (2005, Jan. 15). Taking student success seriously: Rethinking the first year of college, The 9th Annual Intersession Academic Affairs Forum, Fullerton, CA, USA. http://www.uky.edu/ie/sites/www.uky.edu.ie/files/ uploads/CF (in English).

[8] Tukibayeva, M., Gonyea, R. (2014). High-impact practices and the first-year student. New Directions for Institutional Res., vol. 160, pp. 19-35, 2014. DOI: https://doi.org/10.1002/ir.20059. (in English).

[9] Gahagan, J. and Hunter, M. (2006). The second-year experience: Turning attention to the academy's middle children. About Campus: Enriching the Student Learn. Experience, vol. 11, no. 3, pp. 17-22. Available: 10.1002/abc.168. (in English).

[10] Graunke, S. S. and Woosley, S. A. (2005) An exploration of the factors that affect the academic success of college sophomores. The College Student J., vol. 39, no. 2, pp. 367-377. Available: http://www.freepatentsonline. com/article/College-Student-Journal/133606107.html (in English).

[11] Tobolowsky, B. (2008). Sophomores in transition: The forgotten year. New Directions for Higher Educ., vol. 2008, no. 144, pp. 59-67. Available: 10.1002/he.326. (in English).

[12] Kuh, G. D. (2005). Promoting Student Success: What Campus Leaders Can Do (Occasional Paper no. 1. Bloomington, IN, USA: Indiana Univ. Center for Postsecondary Res. Available: http://nsse.indiana.edu/ Institutional_Report/DEEP_brief_1.pdf (in English).

[13] Nonis, S. and Hudson, G. (2006). Academic performance of college students: Influence of time spent studying and working. J. of Educ. for Bus., vol. 81, no. 3, pp. 151-159. Available: 10.3200/joeb.81.3.151-159. (in English).

[14] Kennett, D. J. and Keefer, K. (2006). Impact of learned resourcefulness and theories of intelligence on academic achievement of university students: An integrated approach. Educational Psychol., vol. 26, no. 3, pp. 441-457. Available: 10.1080/01443410500342062 (in English).

[15] Rosenbaum, M. and Ben-Ari, K. (1985). Learned helplessness and learned resourcefulness: Effects of noncontingent success and failure on individuals differing in self-control skills. J. of Personality \& Social Psychol., vol. 48, no. 1, pp. 198-215. (in English).

[16] Cuseo, J. (2012). Student success: Definition, outcomes, principles and practices. Esource for College Transitions (Electron. Newslett.), Available: http://www.fye.uconn.edu/12F_Wk_Digest/September/Weekly_2012_09_24/ PDF's/Cuseo_Student_Success.pdf (in English).

[17] Shaffer, S. C., Eshbach, B. E., and Santiago-Blay, J. A. (2015). A dual approach to fostering under-prepared student success: Focusing on doing and becoming. InSight: A J. of Scholarly Teaching, vol. 10, pp. 79-91. Available: https://files.eric.ed.gov/fulltext/EJ1074057.pdf (in English).

[18] Kennett, D. J. and Reed, M. J. (2009). Factors influencing academic success and retention following a 1styear post-secondary success course. Educational Res. and Eval., vol. 15, no. 2, pp. 153-166. Available: 10.1080/13803610902804382 (in English). 
[19] Tinto, V. (2012). Enhancing student success: Taking the classroom success seriously. The Int. J. of the First Year in Higher Educ., vol. 3, no. 1, pp. 1-8. Available: 10.5204/intjfyhe.v2i1.119 (in English).

[20] Tinto, V. (1987). Leaving College: Rethinking the Causes and Cures of Student Attrition. Chicago, IL, USA: Univ. of Chicago Press. (in English).

[21] Astin, A.W. (1999). Student involvement: A developmental theory for higher education. J. of College Student Develop., vol. 40, no. 5, pp. 518-529. Available: https://www.middlesex.mass.edu/ace/downloads/astininv. pdf (in English).

[22] Coker, J. S. and Porter, D. J. (2015). Maximizing experiential learning for student success. Change: The Mag. of Higher Learn., vol. 47, no. 1, pp. 66-72. Available: 10.1080/00091383.2015.996101 (in English).

[23] Kuh, G. D., Kinzie, J., Schuh, J. H, and Whitt, E. J. (2011). Fostering student success in hard times,” Change: The Mag. of Higher Learn., vol. 43, no. 4, pp. 13-19. Available: 10.1080/00091383.2011.585311 (in English).

[24] Strom, P. S. and Strom, R. D. (2013). Collaboration and support for student success. Community College J. of Res. and Pract., vol. 37, no. 8, pp. 585-595. Available: 10.1080/10668926.2012.753851 (in English).

[25] Seifert, T.A., Arnold, C., Burrow, J., and Brown, A. (2011). Supporting Student Success: The Role of Student Services within Ontario's Postsecondary Institutions. Toronto, ON, Canada: Higher Educ. Qual. Council of Ontario. (in English).

[26] Hardy Cox, D. and Strange, C. C. (2010). Achieving Student Success: Effective Student Services in Canadian Higher Education. Montreal \& Kingston, QB, Canada: McGill-Queens Univ. Press. (in English).

[27] Bain, K. (2004). What the Best College Teachers Do. Cambridge, MA, USA: Harvard Univ. Press. (in English).

[28] Kuh, G. D. (2013). Promise in action: Examples of institutional success. New Directions for Higher Educ., vol. 161, pp. 81-89. Available: 10.1002/he.20048 (in English).

Nataliia Zakharchuk, Candidate of Pedagogical Sciences, Associate Professor (Ukraine), Philosophy Doctor (Canada), researcher, University of Saskatchewan, Saskatoon, Canada.

\section{INSTITUTIONAL INITIATIVES AND PRACTICES FOR STUDENT SUCCESS: FROM THE EXPERIENCE OF WESTERN UNIVERSITIES}

The paper analyzes the experiences of Western scholars on student success in higher education. The analysis of various perspectives on the student experience in post-secondary institutions allows the author to recognize student success as a dual responsibility of an individual and an institution. In this sense, institutional commitment to student success acts as a prerequisite for student success. The analysis of the relevant literature on student success-oriented initiatives of post-secondary institutions provides sufficient grounds to suggest grouping these services, programs, and strategies into three large categories according to their primary goals. Thus, institutional initiatives may be viewed as exploratory, supporting, and quality-enhancing. Exploratory initiatives aim to explore the range of issues connected to different aspects of students' academic and social life at university, identifying and prioritizing key needs through quantitative findings and case studies. The main goal of this type of institutional initiatives is to determine students' needs and priorities for a subsequent decision on an appropriate institutional trajectory. Supporting initiatives serve as the next logical step to act upon the reported results of exploratory actions. The main goal of supporting initiatives is to provide just-in-time student support of various forms facilitating student engagement and orientation. The goal of quality-enhancing initiatives is to provide opportunities for administrators, teachers, instructors, and advisors to develop further professionally, enhance the quality of their work, and maintain the quality of programs, curricula, and course designs. The results of these institutional practices worldwide lead to the conclusion that students are more likely to achieve success in their academic and social life at post-secondary institutions if the latter are committed to student success.

Keywords: institutional initiative; student success; higher educational institution; institutional commitment; student commitment. 